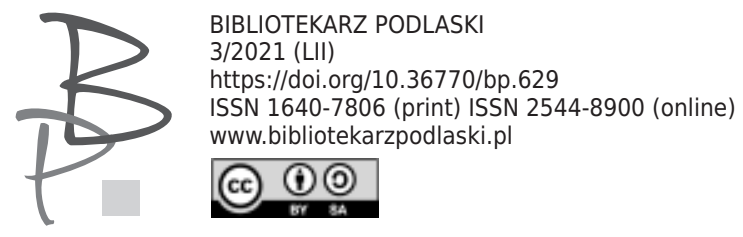

\title{
Olena Saikovska*
}

Odeski Narodowy Uniwersytet im. I.I. Miecznikowa, Ukraina /

/ Odessa I.I. Mechnikov National University, Ukraine

ORCID: 0000-0001-5355-331X

\section{Інтермедіальні коди у творах болгарських фантастів $\mathbf{X X - X X I ~ c T . ~}$}

Codes of intermediality in the Bulgarian fantastic literature of the $20^{\text {th }}-21^{\text {st }}$ centuries

Abstract: The article is dedicated to the study of the intermedial codes in the fantastic works written by the Bulgarian writers of the $20^{\text {th }}-21^{\text {st }}$ centuries. Intermediality as a form of interconnectedness of different types of art is challenging for literature research. The aim of the article is to study the interaction of verbal and audio (music), verbal and visual (pictorial art, architectural models), verbal and performing/synthetic (cinema, theatre) arts. The object of the research is the Bulgarian fantastic literature of the $20^{\text {th }}-21^{\text {st }}$ centuries, where the subject is codes of intermediality. The method of intermedial studies proves to be fruitful for this type of research work. As a result, it is stated that the variants of ekphrasis (picture-ekphrasis, urboekphrasis, oikoekphrasis, musical ekphrasis), "ekphrastic transition" and the interaction of verbal and audio, verbal and visual, verbal and synthetic arts are implemented in the Bulgarian fantastic literature of the $20^{\text {th }}-21^{\text {st }}$ centuries.

* Olena Saikovska - PhD, doc., dr., pracuje w Katedrze Lingwistyki Ogólnej i Słowiańskiej Odeskiego Narodowego Uniwersytetu im. I. I. Miecznikowa (Ukraina). Autorka pracy: Intermediality of Pavel Vezhinov's prose (2019). 
Keywords: comparative studies, Bulgarian literature, intermediality, ekphrasis, arts, fantastic literature.

Інтермедіальність як долання меж між різними видами мистецтва - актуальний напрям для вивчення мистецьких творів XX-XXI століття. Трансгресивність літератури, проникнення у iï простір кіно, живопису, музики є специфікою творів (пост)модернізму, що характеризуються розширенням текстуальних меж. Фантастична література за своєю природою $є$ синкретичною, переважно з нелінійною складною хронотопною конструкцією, ігровими елементами, вона формує окремі пласти «вторинної реальності». Літературну фантастику розглядають як метажанр (О. Стужук $)^{1}$, оскільки це дає змогу «стирати» чіткі межі родової приналежності, розширюючи горизонти та можливості фантастичних творів.

Болгарська фантастика стала об'єктом дослідження таких сучасних болгарських літературознавців, як-от: Г. Гачев, В. Іванов, А. Ілієва, Е. Константинова, К. Ненов, Х. Поштаков, О. Сапарев, А. Славов, Л. Стоянова, А. Хелс. Їхні праці присвячені вивченню наукової фантастики (О. Сапарев), історії фантастики та поетики окремих фантастичних творів (Л. Стоянова), теоретичному осмисленню поняття „фантастика” (Е. Константинова), розвиткові сучасної болгарської фантастичної літератури (Н. Аретов, Р. Ликова, Х. Поштаков, А. Славов), специфіці жанрових різновидів - фентезі (історичне, гумористичне, міфологічне, слов'янське), кіберпанку, міфологічної, соціальної, філософської фантастики, альтернативної історії (Г. Гачев, В. Іванов, А. Ілієва, К. Ненов, А. Славов, А. Хелс). Питання сучасної болгарської фантастики, пов'язані з творчістю окремих персоналій, фантастичним у художньому слов'янському світі, аналізом поодиноких творів, висвітлювали такі українські науковці, як О. Зарицький, В. Захаржевська, В. Климчук, О. Сливинський. У дисертації О. Сайковської „Сучасна болгарська фантастика: генеза, жанрові

1 О. Стужук. Художня фантастика як метажанр (на матеріалі украӥнської літератури XIX-XX cm.): дис... канд. філол. наук : 10.01.06. Київ, 2006. с. 176. 
модифікації та поетика"² окреслені специфічні риси сучасної літературної фантастики та детально проаналізовані основні етапи у розвитку болгарської фантастичної літератури. I хоча кожен із них має унікальні риси, незмінною характеристикою залишається «вихід за межі» тексту. Метою цією наукової розвідки є проаналізувати прояви інтермедіальності у фантастичних творах болгарських письменників XX - XXI століття.

Болгарська літературна фантастика (беручи витоки ще з міфу та чарівної казки) почала активно розвиватися на початку XX століття. У період після Визволення болгари намагалися отримати освіту в європейських університетах. Слухаючи лекції з філософії, історії, літератури, права, молоді люди вважали, що акумулювали достатньо знань і сил, аби оновити мислення болгарського народу та започаткувати новий етап розвитку мистецтва у Болгарії. На таких переконаннях формувалися нові модерні літературні і мистецькі угрупування. У 1892 році вперше побачив світ літературний журнал „Мисъл” (укр. «Думка»), який видавався групою інтелектуалів: доктор Кристьо Кристев, Пенчо Славейков, Пейо Яворов, Петко Тодоров. I якщо головний редактор, доктор Кристьо Кристев (д-р Кръстьо Кръстев), був мислителем та ідеологом нової літературної формації, то його сподвижники стали відомими болгарськими письменниками, втілюючи модерні ідеї у своїх літературних творах та критичних статтях.

Письменників, які належать до літературного кола „Мисъл”, не вважають фантастами цілком справедливо, але звернення до категорії фантастичного у їх творах присутне. Надзвичайно продуктивним представником цього літературного угрупування $є$ Пенчо Славейков, творчість якого традиційно поділяють на гри групи - фольклорні стилізації, ліричні мініатюри та філософські поеми ${ }^{3}$. Саме третя група творів формує своєрідний літературний паспорт поета, а назви творів вже вказують на шляхи інтермедіальної взаємодії - „Симфония на безнадежността” („Симфонія безнадіï”), „Химни за смъртта на сврьхчовека” („Гімни про смерть надлюдини”), „Микел Анджело” („Мікеланджело”), „Сis moll”. Особли-

2 О. Сайковська, Сучасна болгарська фантастика: тенеза, жанрові модифікаиії та поетика: дис... канд. філол. наук : 10.01.03. Київ 2015, с. 216.

3 Р. Хаджикосев, История на българската литература (1878-1918). Букурещ: Университетско издателство в Букурещ, 2003, С. 139. 
ву увагу заслуговує антологія „На острова на блажените” („На острові блаженних”) (1910р.), яку вважають „наймодерністичною книгою нової болгарської літератури” завдяки симбіозу поезії і прози, різних жанрів і стилістичних моделей, безкінечним цитатам, автоцитатам и псевдоцитатам $^{4}$. Книга є літературною містифікацією, яка представляє творчість письменників невідомого народу, що живе на невідомому острові (цей елемент фантастичного П. Славейков використовує як модерний прийом). Структурована як антологія з короткими літературними портретами та коментарями, книга містить твори і навіть зображення фіктивних поетів, які, по суті, є зображеннями самого П. Славейкова різних років з різним деталями - шапкою, окулярами, люлькою тощо. У центрі зображення - театр на невідомому острові: „Театр перетворюється з Балаканини на храм слова. Храм творчої уяви. 3 тих пір і до сьогодні на Острові Благословенних - де немає церков, які вбивають всяку повагу до Творця і його слова, - храмом Божим є театр і піднесеним творчим словом служить життю і найвищим духовним потребам"5. У цьому фантастичному світі острова благословенних, театр стає храмом. Його функція - встановлення контакту з трансцендентним. Для письменників кола „Мисъл” фантазія та ілюзія розуміються як „можливість подолання меж фактичного існування через його трансцендентність у духовному плані”“. По суті, театр виконує функцію екфрастичного переходу в світ духовного.

У 20-х роках XX століття (після Першої світової війни) розвивається інший тип фантастики, яку науково осмислює й номінує О. Сапарев у розвідці „Болгарська діаболічна фантастика”7. Літературний авангард

4 Там же, с. 149 : «...като литературен факт тази чудновата симбиоза от поезия и проза, различни жанрови и стилистични модели, безкрайни цитати, автоцитати и псвдоцитати, в крайна сметка се превръща в най-модернистичната книга в новата българска литература».

5 П. Славейков, На Острова на блажените. Събрани съчинения. Т.5. С. 346: «Театрът се превръща от Бърборище в храм на словото. Храм на творческата фантазия. Оттогава и до днес на Острова на блажените - дето няма черкви, убиващи всяка почит към Твореца и словото му - храм божий е театрьт и с възвишеното творческо слово се богослужи на живота и висшите душевни потребности».

6 Б. Пенчев, Българскиятм модернизъм: моделирането на Аза. София: УИ «Св. Климент Охридски», 2012. С.38 : «способността за преодоляване на фактичността на съществуването чрез трансцендирането му в плана на духовното».

7 О. Сапарев, Българска диаболична фантастика / Игра на сенките. Пловдив : Христо Г. Данов, 1983. С. 3-24. 
створив сприятливі умови для формування такого напряму, характерного для болгарської літератури, як діаболізм (складова частина експресіонізму 20-х років, який гіперболізує жахливе й перетворює його на самоціль зображення). Л. Стоянова зазначає, що однією зі специфічних особливостей болгарського романтизму і символізму до війни стала відсутність надприродного та напруженої атмосфери, яка його створює. Після війни картина змінилася: війна загострила погляд митців на злочинне, страшне $^{8}$. Тож фантастика жаху не $є$ випадковим явищем, вона виникла під впливом доби - була народжена жахами війни. У болгарських діаболістів формується концепція диявольського всередині Людини, де в темній душі ховається злість, заздрість, низькі пристрасті та жорстокість. Г. Райчев, С. Мінков і В. Полянов не залишилися лише в межах концепції цього жанру, вони створили прозу, що характеризується експресіоністичним і символістичним настроєм (відгомін цих настроїв знайдемо в літературі 60-70 років XX століття - романах Л. Ділова, П. Вежінова; сучасних болгарських хорор - творах Е. Павлової та ін.).

Естетика письменників-діаболістів підкреслено зневажала реальне життя, людські дії та конфлікти у їх звичному прояві. Душа протиставлялася здоровому глузду та виступала об'єктом аналізу у іï хворобливій формі, люди не сприймалися як мислячі істоти, а лише як раби містичної сили, письменників цікавили таємні, жахливі, загадкові прояви душі - привиди, вбивства, самовбивства, марення. На творчість Светослава Мінкова значний вплив мав Е. По, особливо характерна для нього сила зображення. Від Г. Майнрінка він успадкував принцип зображення реального, земного як символу потойбічного, де неможливо чітко розмежувати дійсність від сну („Великий” Г. Майнрінка та оповідання „Заключени” (,Замкнені”), „Полунощна история” („Нічна історія”), „Синята хризантема” („Синя хризантема”). Так, наприклад, герої мінковської „Синьої хризантеми”, по-мертвецькому п'яні, з галюцинаціями, розмовляють iз мертвими, поступово самі втрачають свідомість тощо. Атмосфера завжди апокаліптична, що збуджує уяву; вчинки героїв безумні й навіть мають страшні наслідки. Але особливим є те, що причини усякого кошмару, без-

8 Л. Стоянова, Преображения на фантастичното в българската проза. София: Академично издателство «Проф. Марин Дринов», 1996, С. 10. 
умства, садистських проявів розкриті й вміщені в історичну обстановку післявоєнного міста. Така особливість болгарського діаболічного оповідання, як акцент на міській оптиці, визначає його специфіку й відокремлює від західноєвропейського. Місто виступає варіантом урбоекфразису у центрі новел збірки.

Продуктивним для аналізу є новела „Sérénade mélancolique” С. Мінкова 3 тієї ж збірки „Синя хризантема”, в якому інтерпретується мотив вічності мистецтва та тлінності плоті й любові. Новелу можна назвати текстом-мелоекфразисом, оскільки музика у ній присутня на всіх рівнях. Дія розгортається у місті, яке вважається одним із центрів музичного мистецтва - у Відні (вже в першому реченні йдеться про королівську оперу). Опозицією до опери є місце регулярного відпочинку - героя 3 промовистою назвою кабаре „Дяволската пеперуда” („Диявольський метелик”), що вже апелює до читацької уяви, готуючи до чогось надзвичайного.

Головний герой, який працює в кіноіндустрії, змінює помешкання і зупиняється на квартирі, де живе інша квартирантка, молода полька, яка має дивну звичку грати на скрипці кожної ночі о першій годині. Справді, о зазначеній годині щоночі звучить дивна меланхолійна серенада. Музика трансгресує у світ героя, змушуючи по-новому „слухати” твір. Структура „Sérénade mélancolique” П. Чайковського (до цього музичного твору апелює С. Мінков) не лише втілюється, але й інтерпретується новелі. Оригінальний музичний твір складається з чотирьох частин : I. Pezzo in forma di sonatina (П’єса у формі сонатини), II. Valse (Вальс), III. Elegia (Елегія), IV. Finale (Tema russo) (Фінал (на російську тему). У творі С. Мінкова скрипалька грала мелодію п'ять разів, останній раз, певно, виступаючи співтворцем мелодії: „І з кожним новим повторенням ії мелодія сильно врізалася в мою душу, я розумів, що чиясь таємниця розкривається, щось зі мною відбувається. Бо це був дикий сміх долі, це була пісня відкинутих, це була біла літургія любові. А через кілька ночей мені приснилася пані Паола. Але до того часу я ніколи не бачив іiі. I хто знає, можливо ця дивна риса моєї любові передасться і подіям, про які я хочу розповісти"”.

9 С. Минков, Sérénade mélancolique. URL: https://chitanka.info/text/26222-serenademelancolique/0 : «И с всяко ново повтаряне нейната мелодия се врязваше властно в душата ми, аз разбирах, че се разкрива нечия тайна, с мене ставаше нещо. Защото това беше дивият смях на съдбата, това беше песента на отвергнатите, това беше бялата литургия на любовта. 
У результаті надзвичайного пливу музики головний герой закохується у дівчину. Але в той день, коли він хоче зізнатися ій у коханні, хазяйка квартири повідомляе, що пані Паола померла. Після ії смерті починають відбуватися дивні та страшні речі. Герой бачить, що насправді скрипалька не молода гарна дівчина, а жінка 3 потворним обличчям, а аї скрипка „вміє” сама грати знайому серенаду. С. Мінков знову „заводить” головного героя у диявольське кабаре (місце переходу у світ фантастичного), після чого відбуваються фантастичні жахливі події: „А однієї пізньої ночі, коли я повернувся додому, сталося таке, що я мало не збожеволів. Коли я застилав ліжко, у моїй кімнаті почувся гучний тріск. Кришка коробки, в якій була захована скрипка пані Паоли, відкрилася, а сама скрипка стрибнула, пролетіла над моєю головою і піднялася до столу ${ }^{10}$. Перелякавшись, юнак вирішує продати стародавню скрипку, якій близько 100 років, й отримує непогані гроші за неї. Але „жахіття” не завершуються. Через деякий час незнайомець приходить до героя у кімнату, говорить, що юнак погано зберігає свої спогади, й залишає на столі скрипку пані Паоли. Згодом хлопець бачить на столі зошит з любовними віршами та потворну голову пані Паоли 3 тріумфуючою посмішкою на устах. Завершується оповідання словами: „А хтось грав Sérénade mélancolique”. Музика „звучить” і після прочитання оповідання. Подібні інтермедіальні коди використані у творах болгарських фантастів 60-80-х років XX століття (,золотої ери” болгарської фантастики), наприклад, у творах Павела Вежинова.

Піктуроекфразисом вважаємо фантастичну новелу С. Мінкова „Малвина” („Мальвіна”) ${ }^{11}$. Письменник переосмислює мотив ілюзорного існування непорочності та вічної краси й інтерпретує відомий у світовій літературі сюжет магічної підміни реального ірреальним, у манері, схожій до творчої інтерпретації О. Уайльда в романі „Портрет Доріана Грея”.

А няколко нощи по-късно аз мечтаех за пана Паола. Но дотогава аз нито веднъж не бях я виждал. И кой знае, може би този странен характер на любовта ми се предаде и на събитията, за които мисля да разкажа».

10 Там же: «А една късна нощ, когато се върнах в къщи, се случи нещо такова, че аз едва ли не полудях. В момента, когато оправях леглото си, един силен тряськ се чу сред стаята ми. Капакьт на кутията, в която беше скрита цигулката на пана Паола, се разтвори, а самата цигулка скочи, прелетя над главата ми и се възправи на масата».

11 С. Минков, Малвина. URL: https://chitanka.info/text/1584-malvina 
Головний герой - художник - малює надзвичайно красиву жінку - Мальвіну. Коли йому залишається дописати кілька останніх штрихів (які необхідні для завершення цього шедевру), жінка-натурщиця зникає. Картина $\epsilon$ порталом, крізь який переходить головна героїня зі світу людей у світ трансцендентного і навпаки. А художник, який мріяв закарбувати на полотні вічне, залишається оповитий жахом.

Патологічна свідомість діаболічної літератури співзвучна 3 фантастичною літературою другої половини ХХ століття. Цікавим варіантом взаємодії літератури 3 іншими видами мистецтва $є$ твори болгарського письменника 60-80-х років XX століття Павела Вежинова, які виявилися надзвичайно продуктивними для вивчення інтермедіальних кодів та проаналізовані у статті О. Сайковської ${ }^{12}$. Роман „Нощем с белите коне” („Вночі з білими кіньми”, 1975) реалізовує мотив фантастичного проникнення у картину. Повість „Бариерата” („Бар’єр”, 1976) використовує музику як екфрастичний портал між світом реального та ірреального (земного життя - ірраціонального польоту), а балет П. Чайковського „Лебедине озеро” дає підстави розглядати повість П. Вежинова як повість-екфразис-балет (а не лише як мелоекфразис). Новелу „Сините пеперуди” („Сині метелики”, $1968)$ також можна розглядати як мелоекфразис, оскільки метелики самі $€$ творцями i „споживачами” музики. Тут прозорими є алюзії на оповідання С. Мінкова на рівні образів метелика, композитора, музиканта тощо.

Текст-екфразиз іншого письменника кінця XX століття Віктора Паскова „Балада за Георг Хених” („Балада про Георга Геніга” 1987) оприявлює музику як артефакт, що пронизує твір на рівні композиції (текст побудований як музична балада Ф. Шуберта „Вільшаний король”, з чергуванням теми і контратеми), жанру (балада), тематичному (оповідь про майстра виготовлення скрипок), образному (головними є образи скрипки, майстра-скрипаля, музики, оркестру, священного мистецтва). Фантастичні образи тіней, які щовечора приходили з потойбіччя, допомагають здійснити екфрастичний перехід. Головному героєві (маленькому хлопчику Віктору) завжди здавалося, що саме вони заберуть майстра Геніга у царство мертвих, коли прийде час.

12 О. Сайковська, Інтермедіальні виміри прози Павела Вежсинова, Езиков свят. Кн. 1. Благоевград: Югозападен университет „Неофит Рилски“, 2019, Том 17, С.126-132. 
Міфологічний образ коня-пегаса, який переносить у засвіти, використаний і у романі „Вночі з білими кіньми”, і в „Баладі про Георга Геніга”. У романі П. Вежинова коні відображають духовний шлях у мистецтві, яке не потрібно намагатися зрозуміти з першого погляду. „Білі коні” - картина, яка зображена в центрі роману, - це мрія, страждання за недосяжним. Кінь В. Паскова - войовничий, буйний, з його ніздрів палає вогонь, з-під копит летять іскри, а верхи неодмінно сидить покійний брат Георга Геніга Антон, що грає на валторні. Світ Георга Геніга сповнений казковості, магічних заклинань та таємничих загадок, що здавалося дивним і чарівним малому Віктору.

Обидва автори є письменниками міста, тому урбоекфразис (та ойкоекфразис) знаходять своє відображення у їх творах. Софія - столиця Болгарії - представлена різними видами топосів: 3 одного боку змальоване реалістичне місто, а з іншого (частіше вночі) - це ж місто/будинок $є$ виходом у простір трансцендентного, фантастичного (тут можливі польоти, розмови з тінями тощо).

Іншим варіантом взаємодії різних видів мистецтва $\epsilon$ інтеракція література-кіно. На початку XX ст. очевидним став факт такого зближення. В 1920-ті роки „кінохвиля” у болгарській літературі була вже вельми помітною. Багато хто безпосередньо прилучається до роботи над кіносценаріями. Нікола Вапцаров не лише долучається до дискусії болгарських митців „кіно чи театр”, а й пише поезії, у яких використовує кіно в літературному тексті. У поезії „Кіно” трансгресивність проявляється на кількох рівнях: проблематизація дискусії навколо видів мистецтва та жанрів, використання метамови театру для кіно, поєднання і зіставлення кадрів завдяки монтажу, динамічність оповіді. Кожен епізод і власне весь сюжет в їх драматичній та логічній послідовності розвиваються завдяки монтажу. „Кіно” - поезіямонтаж, подібна до німих кінострічок з їх чітким чергуванням загальних планів та вихвачених камерою деталей. Метод паралелізму лягає в основу кожної сцени (назва фільму - „Една човешка драма”, а завершується поезія словами: „И после... Сивия живот,/ борба за хлеб,/ мечти неясни;/ и вечер тесното легло,/ в което неусетно гаснем.../ Това е то./ Това е драмата ${ }^{13}$.

13 Н. Вапцаров. Кино. URL: https://www.slovo.bg/showwork.php3?AuID=17\&WorkI$\mathrm{D}=167 \&$ Level $=1$ 
„Відображений” образ показує явище не прямо, а через виділення з нього одного компонента, „прикмети” (очі дівчини у кадрі - поезія „Кіно”). „Парціально-монтажний” образ відображає ціле, створене 3 „мозаїки”, коли око митця інтенсивно охоплює окремі сторони явища (зображення декорацій: ліс, небо, шосе, лімузини, герої - поезія „Кіно”).

Н. Вапцаров не був фантастом, але ,апробовані” у його поезіях прийоми кіно знайшли продовження у романі сучасного болгарського фантаста. У 2003 році побачило світ гумористичне фентезі Христо Поштакова „Меч, міць і магія”14, яке відносять до пародійної казково-фантастичної моделі фентезі ${ }^{15}$. Х. Поштаков використав германо-скандинавський міф як основу для свого роману-фентезі, але головні дійові особи зображені не героїчні постаті. Скоріше це чарівні невдахи: сміливий, але бідний, як церковна миша, мандрівний лицар Барді, змарнілий від голоду дракон Дзог і маг-невдаха Горо. Така строката компанія одного чудового дня і переноситься в іншу реальність - сучасний кінематографічний Голівуд. Фентезі побудоване як кінострічка, яка постійно переносить героїв з одного виміру (бідна середньовічна країна Ландирія) у сучасний Голівуд, до вони стають акторами. Порталом переходу між світами обрано „неправильне” магічне закляття (в напрямку Ландирія-Голівуд) та комп'ютер (у зворотному напрямку). Письменник зображує два сюжети: пародію на лицарський роман і зйомки сучасного бойовика, що побудовані за усіма канонами кіно. Кіно, як артефакт, який пронизує фентезі на всіх рівнях його структури (тема, сюжет, принципи композиції, образи, мовностилістичне вираження) дає підстави розглядати твір Х. Поштакова як текст-екфразис.

Інтермедіальні коди болгарської літературної фантастики XX-XXI століття реалізуються через мелоекфразис, піктуроекфразис, урбоекфразиз (ойкоекфразис), кіно, прийом фантастичного як екфрастичного порталу/переходу і провокують до здійснення подальшого наукового аналізу.

14 Х. Пощаков, Меч, мош и магия. URL: http://chitanka.ddns.net:8080/text/1059-mechmosht-i-magija

15 О. Сайковська, Логіка фантастичного у Хрісто Поштакова (на матеріалі романуфентезі «Меч, мічь $і$ магія»), Компаративні дослідження слов'янських мов і літератур: Пам'яті академіка Леоніда Булаховського: збірник наукових праць. Випуск 18. Київ : «Освіта України», 2012, С. 319-327. 


\section{Література}

Вапцаров Н. Кино. URL: https://www.slovo.bg/showwork.php3?AulD=17\&Workl$\mathrm{D}=167 \&$ Level $=1$

Минков С. Малвина. URL: https://chitanka.info/text/1584-malvina

Минков C. Sérénade mélancolique. URL: https://chitanka.info/text/26222-serenademelancolique/0

Пенчев Б. Българският модернизъм: моделирането на Аза. София : УИ «Св. Климент Охридски», 2012. 253 с.

Пощаков X. Меч, мощ и магия. URL: http://chitanka.ddns.net:8080/text/1059-mech-mosht-i-magija

Сайковська О. Інтермедіальні виміри прози Павела Вежинова . Езиков свят. Кн. 1. Благоевград: Югозападен университет „Неофит Рилски“, 2019. Том 17. C.126-132.

Сайковська О. Логіка фантастичного у Хрісто Поштакова (на матеріалі романуфентезі «Меч, міць і магія»). Компаративні дослідження слов'янських мов і літератур : Пам'яті академіка Леоніда Булаховського : збірник наукових праць. Київ : Освіта України, 2012. Випуск 18. С. 319-327.

Сайковська О. Сучасна болгарська фантастика: ґенеза, жанрові модифікації та поетика : дис... канд. філол. наук : 10.01.03. Київ, 2015. 216 с.

Сапарев О. Българска диаболична фантастика. Игра на сенките. Пловдив : Христо Г. Данов, 1983. С. 3-24.

Славейков П. На Острова на блажените. Събрани съчинения. София : Български писател. 1959. Т.5. 484 с.

Стоянова Л. Преображения на фантастичното в българската проза. София : Академично издателство «Проф. Марин Дринов», 1996. 162 с.

Стужук О. Художня франтастика як метажанр (на матеріалі української літератури XIX-XX ст.) : дис... канд. фрілол. наук : 10.01.06. Київ, 2006. 176 с.

Хаджикосев Р. История на българската литература (1878-1918). Букурещ : Университетско издателство в Букурещ, 2003. С. 139.

\section{Bibliografia}

Chadżykosiew R. Istorija na błgarskata litieratura (1878-1918). Bukurieszcz: Uniwiersitietsko izdatiełstwo w Bukurieszcz, 2003. s. 139. 
Minkow S., Małwina. URL: https://chitanka.info/text/1584-malvina

Minkow S., Sérénade mélancolique. URL: https://chitanka.info/text/26222-serenademelancolique/0

Pienczew B., Błgarskijat modiernizm: modieliranieto na Aza. Sofija : UI «Sw. Klimient Ochridski», 2012, s 253.

Poszczakow Ch., Miecz, moszcz i magija. URL: http://chitanka.ddns.net:8080/te$x t / 1059$-mech-mosht-i-magija

Saikovska O., Intermedialni vymiry prozy Pavela Vezhynova. Ezykov sviat. Kn. 1. Blahoevhrad: Yuhozapaden unyversytet "Neofyt Rylsky“, 2019. Tom 17, s.126132.

Saikovska O., Lohika fantastychnoho u Khristo Poshtakova (na materiali romanufentezi «Mech, mits i mahiia»). Komparatyvni doslidzhennia slovianskykh mov i literatur: Pamiati akademika Leonida Bulakhovskoho: zbirnyk naukovykh prats. Kyiv : Osvita Ukrainy, 2012. Vypusk 18. s. 319-327.

Saikovska O., Suchasna bolharska fantastyka: geneza, zhanrovi modyfikatsii ta poetyka: dys... kand. filol. nauk : 10.01.03. Kyiv, 2015. s. 216.

Sapariew O., Błgarska diaboliczna fantastika. Igra na sienkitie. Płowdiw: Christo G. Danow, 1983. s. 3-24.

Sławiejkow P., Na Ostrowa na błażenitie. Sbrani sczinienija. Sofija: Błgarski pisatieł. 1959. T.5, s. 484.

Stojanowa Ł. Prieobrażenija na fantasticznoto w błgarskata proza. Sofija: Akadiemiczno izdatiełstwo «Prof. Marin Drinow», 1996, s. 162.

Stuzhuk O.. Khudozhnia fantastyka yak metazhanr (na materiali ukrainskoi literatury XIX-XX st.): dys... kand. filol. nauk : 10.01.06. Kyiv, 2006, s. 176.

Wapcarow N. Kino. URL: https://www.slovo.bg/showwork.php3?AuID=17\&WorkI$\mathrm{D}=167 \&$ Level $=1$ 